\title{
Supportive Work Environment and Teacher's Innovative Work Behaviour: The Mediating Role of Informal Learning in Vietnam
}

\author{
Dr. Nguyen Duy Phuong ${ }^{1, *}$, MA. Pham Huong Quynh ${ }^{2}$ and MA. Hoang Thi Thu Hien ${ }^{3}$ \\ ${ }^{1}$ University of Labour and Social Affairs, No. 43 Tran Duy Hung - Trung Hoa - Cau Giay - Ha Noi - Vietnam \\ ${ }^{2}$ Faculty of Human Resource Management and Economics - National Economics University - No.207, Giai Phong \\ - Hai Ba Trung - Hanoi - Vietnam \\ ${ }^{3}$ Technology, Economy and Fishery College, No. 804 Thien Loi - Kenh Duong - Le Chan - Hai Phong - Vietnam
}

\begin{abstract}
This study aims to assess the relationship between the supportive work environment (SWE), informal learning (IFL), and the innovative work behaviour (IWB) of general school teachers. The stratified sampling method is used to select 471 teachers from general public schools in Vietnam. Data are analysed using the Structural Equation Modeling (SEM) technique with AMOS 22. As per findings, a supportive work environment is critical to predicting teacher' innovative work behaviour. Informal learning is a partially mediator in the relationship between the supportive work environment and innovative work behaviour. New findings are found regarding the impact of teachers' informal learning on innovative teaching behaviour. Therefore, some recommendations for educational administrators are also included in the study to encourage innovative teaching behaviour through informal learning promotion.
\end{abstract}

Keywords: supportive work environment, informal learning, general education teachers, innovative work behaviour. JEL Classifications: D83, I210

\section{INTRODUCTION}

Amid the current globalism, innovation is seen as one of the important elements of an organisation's sustainability and success (Anderson et al., 2014; West \& Farr, 1990). Importantly, harnessing and maximising employees' innovative and innovative capabilities should be a top priority. Creative and innovative ideas introduced and put into practice by employees offer a huge competitive advantage revealed in product or service quality (Park et al., 2014). Employee contributions to organisational innovation are referred to as innovative work behaviour (IWB). It includes activities from idea generation to idea realisation to improve the workflow or resolve work-related issues for the best results (De Jong \& Den Hartog, 2008; Janssen, 2000; Kleysen \& Street, 2001; Scott \& Bruce, 1994; West \& Farr, 1990). The success of this process is attributable to human capital optimization in an organisation (De Spiegelaere et al., 2012). On the other hand, innovative work behaviour in employees is not only beneficial to business performance but also reciprocally conducive to employee development, better work performance and higher job satisfaction (Huhtala \& Parzefall, 2007; Li \& Hsu, 2016; Robinson \& Beesley, 2010).

To provide greater insights into innovative work behaviour, the number of scientific studies on this subject is growing. However, the bias in the experimental studies can be clearly

\footnotetext{
*Address correspondence to this author at University of Labour and Social Affairs, No. 43 Tran Duy Hung - Trung Hoa - Cau Giay - Ha Noi - Vietnam, Tel: +84 903427637; E-mail: nguyenduyphuong@ulsa.edu.vn
}

seen. Most scientific studies have been conducted primarily in for-profit organisations, mostly in the fields of business services, engineering, and technology (Zainal \& Matore, 2019). Meanwhile, according to Thurlings et al. (2015), research on the innovative work behaviour of employees in non-profit organisations, specifically in educational institutions, is very limited. The stability of these organisations, thanks to the state's support, does not mean that innovation from employees is redundant. Accordingly, three main reasons are put forward to emphasise the necessity of innovative teaching behaviour (Gkorezis, 2016; Thurlings et al., 2015; Zainal \& Matore, 2019). Firstly, society nowadays is changing rapidly as the number of students is higher, areas of knowledge are broader, new responsibilities and social expectations also set higher requirements. Thus, employees, particularly school teachers, are expected to engage in continuous innovative work behaviour in general and in teaching in particular so that the students not only acquire academic literacy but also master soft skills like creativity, critical thinking, problem-solving (Bawuro et al., 2019; Nemeržitski et al., 2013; Zainal \& Matore, 2019). Secondly, there are increasingly developed technologies for teaching and learning purposes, so the old teaching method may be outdated and unfit for the current needs of education (Zainal \& Matore, 2019). Hence, teachers are required to continually engage in innovative work behaviour to ensure that the teaching methods in use are still appropriate. Thirdly, according to Gkorezis (2016), Zainal \& Matore (2019), teachers are most frequently in direct contact with students. Their personal behaviours are shared and demonstrated to the students, serving as a great example for students. As such, schools is al- 
ways a starting point for innovation, thereby maintaining social competitiveness.

Overall, innovative teaching behaviour is considered as the core element of this profession, playing an important role in the development of the education system, and establishing the foundation for a knowledge society. Therefore, innovative teaching behaviour (ITB) deserves more attention and requires the workforce administration to seek more insights to introduce appropriate solutions. (Messmann \& Mulder, 2011) In other words, research into innovative teaching behaviour is also imperative and vital to education as research into this behaviour of employees in other fields.

In reality, the three most noteworthy aspects of innovative teaching behaviour are: i) Demographic factors; ii) Individual factors and iii) Organizational factors. However, previous scientific studies only analyse each factor separately, without revealing the interrelationships between these factors or determining if they have a direct or mediate impact on teacher's innovative work behaviour in teaching. In particular, it is suggested by Thurlings et al. (2015) that organisational support is influential on learning behaviours (Evers, 2012), while learning behaviours, in several ways, are related to innovative behaviours. Therefore, this gap is the focus of our research. The reason is that in recent studies on innovative work behaviour, Janssen (2005), Montani et al. (2012), Prieto \& Pérez-Santana (2014) Rehman et al. (2019) are of the same opinion that the supportive work environment in the organisation positively impacts the employees' innovative work behaviour. Nevertheless, with more insights into the aspects of this behaviour, including idea generation, idea promotion and idea realisation, Binnewies \& Groomer (2012) conclude that organisational support only affects idea promotion and idea realisation, while its relationship with idea generation remains unclear. As such, the relationship between a supportive work environment in the organisation and innovative work behaviour may not only be directly influential, but also impacted by mediator variables. On the other hand, according to Evers (2012), organisational support has a positive impact on teacher's learning behaviour during their career development. Whereas learning behaviour, especially informal learning (IFL), is affirmed to have a positive impact on teacher's creativity (Lecat et al., 2018). Therefore, the role of informal learning needs to be clarified in the relationship between a supportive work environment and innovative teaching behaviour. In other words, the objectives of this study include: i) Evaluating the direct impact of specific characteristics of the supportive work environment (including supporting managers and peers) on innovative teaching behaviour; ii) Evaluating the direct impact of informal learning on innovative work behaviour; and iii) Evaluating whether informal learning can be seen as a mediator variable between a supportive work environment and innovative teaching behaviour.

\section{LITERATURE REVIEW AND HYPOTHESES DE- VELOPMENT}

\subsection{Teachers' Innovative Work Behaviour}

Nowadays, innovation is vital not only for organisations in highly competitive fields such as economy, engineering, technology to survive and thrive, but also for non-profit organisations, such as schools (Thurlings et al., 2015; Zainal \& Matore, 2019). Moreover, teachers are considered as knowledge workers who constantly innovate and enhance teaching skills through sharing (McCharen et al., 2011). Therefore, teachers' job is always associated with innovation, and innovative teaching behaviour is an indispensable part of school innovation (Hashim et al., 2019). According to Bawuro et al. (2019), novel ideas in teaching and learning are initially generated. Then, ideas are promoted when teachers are forced to change teaching methods with new curricula or new technology in teaching. Finally, idea realisation means implementing innovative ideas in teaching to improve the teaching quality and learning capabilities of students. As per Messmann \& Mulder (2012), teachers' innovative work behaviour is more specifically described, including observing, listening and aligning ideas, developing strategies, assessing and modifying innovative behaviours.

In general, current studies in education is in agreement with Janssen (2000) that teachers are proactive in generating new ideas to solve problems in teaching, boosting, developing or modifying teaching methods so that class activities promote student creativity and bring good learning outcomes (Klaeijsen et al., 2018; Nemeržitski et al., 2013). Three aspects that are most commonly analysed in teachers' innovative work behaviour include: Idea generation, idea promotion, and idea realisation. Normally, these activities are also simultaneous, thereby teachers may implement creative ideas right in the classroom.

Idea Generation: In the school setting, idea generation involves analysing and exploring to achieve creative teaching methods that stimulate the best knowledge acquisition capabilities of students (Hashim et al., 2019). In reality, the focus of teachers is to engage students in the lesson to identify their problems in learning. For that reason, teachers are motivated to change their way of thinking to solve learning issues.

Idea Promotion: In the education setting, the development of new teaching methods to achieve effective education is connected to encouragement, motivation, support from peers and the school's board of directors and supervisors. Therefore, teachers are recommended to suggest innovative teaching ideas actively and ensure they are shared in the school (Messmann \& Mulder, 2011).

Idea Realisation: At this stage, innovative ideas need to be applied within the teacher's teaching methods, although sometimes they are totally different from the conventional methods. To realise the ideas, the teacher is required to shape the idea into a lecture, lesson plans or new teaching instruments and tools. That way, innovative ideas can be proved to have a positive impact on students' learning outcomes and contribute to improving the teaching quality of the school (Hashim et al., 2019).

\subsection{Informal Learning of Teachers}

Workplace learning is the process of engaging individuals in training programs and courses, as well as acquiring experiences via interaction with peers to gain and share the necessary knowledge to meet organisational needs. (Jacobs \& 
Park, 2009) In this approach, the effectiveness of workplace learning is closely related to the chosen form of learning (Poell, 2013; Tynjälä, 2008). Formal learning and informal learning are the two most common forms of learning in the workplace (Manuti et al., 2015). However, informal learning accounts for up to $75 \%$ of learning in organisations (Noe \& Kodwani, 2018). According to Marsick \& Watkins (2001), the term "informal learning" is characterised by the following four basic principles:

(i) Setting: learning outside the formal education environment;

(ii) Awareness: unintentional or accidental learning;

(iii) Experience: practice, comment and review;

(iv) Relationship: learning through mentoring and teamwork.

Initially, informal learning is motivated by the personal desires of the learner to improve knowledge and gain skills to achieve their own and organisational goals (Marsick \& Volpe, 1999). This activity is conducted in the work environment to improve labour productivity, due to challenges from job requirements, or unforeseen needs or spontaneous decisions. It is not organised into a formal curriculum and may not be recognised by the parties involved. Similarly, it is described by Eraut (2004) that informal learning is an unintended, unstructured, and uninstructed form of learning. It tends to occur on a spontaneous and unconscious basis without any stated goals in terms of learning outcomes. Informal learning is heavily embedded in daily tasks. It overcomes some limitations of formal learning with practical, interactive, and sharing opportunities.

\subsection{Supportive Work Environment}

The internal working environment is one of the additional factors that has a significant impact on employees' innovation and creativity (Birdi et al., 2016; Çokpekin \& Knudsen, 2012). In a supportive work environment, employees are able to create, harness and implement new ideas, thereby improving their performance. Typically, employees are provided with support from the organisation in the forms of benefits, compensation and necessary resources (Hoyt \& Gerloff, 1999). Therefore, the attitudes and behaviours of an employee are dependent on their perception of the organisation's supportive work environment. Specifically, positive perceived organisational support has a positive impact on their performance at the workplace, even towards non-work tasks (Eisenberger et al., 2002). Similarly, according to George (2007) and Madjar (2005), when the organisation is willing to recognise and provide positive feedback on the employee's activities, their positive psychological state is boosted, triggering higher levels of innovative work behaviour. Obviously, organisational support is increasingly appreciated by employees in the workplace. In a successful organisation in terms of innovation, there is a supportive work environment that consistently supports employee ideas, innovative employees are rewarded, collaboration is promoted, individuals are not blamed for mistakes and members are encouraged to take risks.

In reality, a supportive work environment is examined in various different aspects. For example, Kraimer \& Wayne
(2004) divide supportive work environment into three categories: (1) Adaptive support, including training related to language and culture; (2) Career support, including individual career plans and professional achievements; and (3) Financial support, including compensation and incentives. Meanwhile, Bhanthumnavin (2003) examines supportive work environment on these three aspects: (1) Emotional support, including care and empathy from peers and supervisors; (2) informational support, in terms of job-related advice and feedback; (3) Material support, including job-related resources.

In this study, the characteristics of a supportive work environment are analysed according to the view of Blume et al. (2010): management support and co-worker support. These specific aspects of a supportive work environment are premises of innovative work behaviour through enhancing employees' perceptions of responsibilities and motivation (Parker et al., 2006).

\subsection{Supportive Work Environment, Informal Learning and Innovative Work Behaviour}

Supportive Work Environment and Innovative Work Behavior.

It is suggested by previous studies that supportive work environment and employees' perceptions of this support are premises of innovative work behaviour (Janssen, 2005; Montani et al., 2012; Prieto \& Pérez-Santana, 2014; Rehman et al., 2019). To explain, individuals tend to have a more positive emotional response if being nicely treated and willingly helped by supervisors and peers. On the other hand, feelings of anger and disappointment with the organisation will be formed if employees do not receive support from the organisation (Eisenberg, 1990; Madjar, 2005). As a result, it is expected that when employees receive management support and co-worker support, innovative ideas will be generated, leading to innovative work behaviour (Madjar, 2005).

To illustrate management support in reality, Oldham \& Cummings (1996) prove that management support has a significant contribution to the number of patents obtained by employees in two years. Likewise, Frese et al. (1999) discover that a higher level of support and encouragement leads to more creative ideas. Therefore, management support is confirmed as an important factor in stimulating innovative work behaviour (Hunter \& Cushenbery, 2011). In other words, it is the basis for research hypotheses:

Hypothesis H1.1: A work environment characterised by management support has a positive impact on innovative work behaviour.

In terms of co-worker support, similar to management support, studies also expect co-worker support to boost innovative work behaviour (Shalley \& Gilson, 2004). As a result, some hypotheses have been successfully proven. For example, the research of Zhou \& George (2001) shows the positive and meaningful relationship between innovative work behaviour and co-worker support through feedback on expertise. As suggested by Parker et al. (2006), co-workers' trust is positively linked to an individual's proactive work behaviours. Co-worker support is seen as a condition for any collaboration, including knowledge exchange, integration and 
creativity (Lee \& Choi, 2003; Prieto \& Pérez-Santana, 2014). In reality, mutual trust facilitates knowledge exchange, exposure to different ideas and new information (Lee \& Choi, 2003; Madjar, 2005; Prieto \& Pérez-Santana, 2014). In short, based on theoretical reviews, the next hypothesis is suggested as follows:

Hypothesis H1.2: A work environment characterised by coworker support has a positive impact on innovative work behaviour.

\section{Informal Learning and Innovative Work Behaviour}

The results of previous studies have confirmed that learning is the key driving force of innovative work behaviour (Keskin, 2006; Lecat et al., 2018). Innovative ideas are implemented through learning, acquiring and sharing new knowledge (Calantone et al., 2002). As explained by Amabile et al. (1996), learning provides the basis for innovative work behaviour by improving related skills and knowledge of the employee. Importantly, in the workplace setting, informal learning is proven to be the most effective form of learning, helping employees to gain more knowledge (Berg \& Chyung, 2008; Jeon \& Kim, 2012). Thereby, employees' learning can be seen as the key to sustaining, developing and boosting innovation (Messmann \& Mulder, 2012). Importantly, sharing knowledge, connecting and discussing with other employees is considered the simplest and most effective way to boost innovation (Borasi \& Finnigan, 2010). In addition, according to several studies in education, informal learning provides teachers with opportunities to develop and implement innovative ideas (Mohammad \& HarlechJones, 2008; Schussler et al., 2007). Therefore, learning, especially informal learning, is essential for teachers to strive for innovative work behaviour. Thus, the next hypothesis in this study is suggested as follows:

Hypothesis H2: Informal learning has a positive impact on teachers' innovative work behaviour.

\section{Mediation of informal learning}

More management support and co-worker support means more expertise, social knowledge, and resources to develop innovative ideas (Oldham \& Cummings, 1996). With a higher level of support, the idea generation, promotion and realisation are more likely to be valued and eventually bring more value (Scott \& Bruce, 1994). According to Eisenberger et al. (2002), gaining tangible and intangible benefits from the organisation on a daily basis enhances an employee's perceived organisational support. As a result, employees are more active in the organisation's activities apart from job duties.

In addition, as support becomes the organisational culture, employees are also encouraged to participate in learning activities (Cormier-MacBurnie et al., 2015; Kwakman, 2003; Skule, 2004). As the key to career development, learning will become the main driving force of innovative work behaviour (Keskin, 2006; Messmann \& Mulder, 2020). According to Joseph \& Dai (2009), when an organisational environment is focused on learning and creating a structure that allows employees to share their own knowledge, employees will feel empowered to learn and be motivated and involved in this activity. This motivation can result in innovation ca- pabilities. Hence, in an organisation that has a firm structure for informal learning, employees are more likely to share their knowledge. In contrast, Lohman (2009) assume that an unsupportive organisational culture restricts informal learning activities within the organisation.

In short, as a result of theoretical reviews of the relationship between the supportive work environment and informal learning and the impact of informal learning on innovative work behaviour, a hypothesis is suggested as follows:

Hypothesis H3: Informal learning has a mediate impact on the relationship between the supportive work environment and teachers' innovative work behaviour.

\subsection{Research Framework}

Fig. (1) summarises the conceptual framework of the study and the proposed hypotheses.

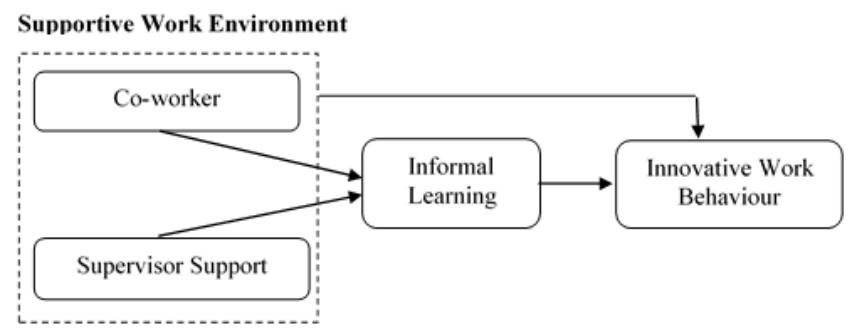

Fig. (1). The proposed conceptual model.

\section{METHODOLOGY}

\subsection{Sample and Procedure}

Before the subjects of this study or teachers were approached, the purpose of the study had been explained to the principals for official permission to conduct the survey right in the schools. With their permission, a group of researchers approached all the teachers and gave instructions before issuing an investigation form. A specific time period during working hours was spared for all teachers to fill out the questionnaire at the same time. The process took about 30 minutes. When the questionnaire was filled out, they were placed in sealed envelopes to ensure the teachers that their reports were anonymous and confidential.

To ensure the samples' representativeness and reliability, the stratified sampling method was combined with convenience sampling and snowball sampling. The total number of participants were 471 teachers from general public schools under the Department of Education and Training of 9 provinces and cities in Vietnam. Data were collected from September 2020 to December 2020.

There are more female teachers than male teachers in every school. Therefore, in all survey samples, female teachers make up $82.6 \%$, while male teachers account for only $17.4 \%$. The average age of the participants is 38.27 years $(\mathrm{SD}=$ 7.296), with ages ranging from 22 years to 53 years old. Years of experience ranges from 1 to 32 years and average at 16.29 years $(\mathrm{SD}=7.511)$ and most teachers have signed indefinite-term labour contract $(86.4 \%)$. In terms of the level of education (elementary, lower secondary, upper secondary), teachers are evenly distributed with a ratio of $38.0 \%$ 
elementary, $37.2 \%$ lower secondary and $24.8 \%$ upper secondary teachers, respectively. All teachers participating in the survey have received college education or above, in which: teachers with university degrees represent the highest share $(53.3 \%)$, followed by teachers with higher education degrees $(29.9 \%)$, and the lowest share belongs to teachers with a college degree $(16.6 \%)$.

\subsection{Measures}

Three main concepts used in this research include supportive work environment (SWE), informal learning (IFL), and innovative teaching behaviour (ITB). Therefore, the measurement scale for these key factors is taken from prior studies and is adapted to the Vietnamese context.

\section{The Supportive Work Environment Scale}

The supportive work environment is measured by developing two multi-item scales to represent aspects of management support and co-worker support. The measurement of management support includes five items created specifically for this study based on the studies of Tracey \& Tews (2005) and Madjar et al. (2002). According to Tracey and Tews (2005), management support focuses on activities that provide opportunities, recognize, and encourage teachers in teaching and enhancing capacity. Additional items in the scale of Madjar et al. (2002) reflect support through feedback and assistance of supervisors in introducing new ideas. To measure co-worker support, five items adapted from Prieto \& Pérez-Santana (2014) are used. All items in the supportive work environment measurement scale are built on a fivepoint Likert scale from $1=$ "strongly disagree" to $5=$ "strongly agree".

\section{The Informal Learning Scale}

In this study, the scale for informal learning is partly based on the scale of Lohman (2006). In this case, teachers are required to assess the frequency of these eight informal learning activities, including (1) talk with others; (2) collaborative with others; (3) observes others; (4) share materials and resources with others; (5) search the internet; (6) scan professional magazines and journals; (7) trial and error; and (8) reflect on your actions. Specifically, the question that the teachers were asked for these activities is "How frequently do you use the following activities when you need to learn something new at work?". The Likert scale ranging from 1 (never using this learning activity) to 5 (always using this learning activity) was used for these items.

\section{Innovative Work Behaviour Scale}

The innovative work behaviour scale used in this study is a modified version of the scale proposed by Janssen (2000), consisting of 9 items, each followed by a five-point feedback scale, from 1 (strongly disagree) to 5 (strongly agree). The innovative work behaviour scale consists of 3 components: idea generation, idea promotion and idea realisation. Sample items include "Creating new ideas for difficult issues", "Mobilizing support for innovative idea", and "Introducing innovative ideas into the work environment in a systematic way".

\section{RESULTS}

\subsection{Reliability and Validity of Scales}

The steps to test the reliability and convergent validity of the scales in this study are suggested by Hair et al. (2009). In particular, Cronbach's Alpha was used to test the reliability of the scales. The items were subject to a Principal Axis Factoring analysis with Promax Rotation (Exploratory Factor Analysis - EFA).

As per results in Table 1, Cronbach's Alpha coefficients in all scales are between 0.8 and 0.95 , fulfilling the Cronbach's Alpha criteria (Nunnally \& Bernstein, 1994). In addition, as EFA results reveal that all items have high factor loadings $(\geq$ 0.5 ) on the construct that they measure and low factor loadings on the construct that they do not measure, it can be concluded that the scales' level of convergence is acceptable. Meanwhile, the Composite Reliability (CR) of all variables is greater than standard level 0.7, and all values of Average Variance Extracted (AVE) are greater than 0.5. Thereby, the scales of variables satisfy the criteria for reliability and convergent validity.

Table 1. Results of Cronbach's Alpha reliability EFA and Convergent Validity.

\begin{tabular}{|c|c|c|c|c|c|c|}
\hline \multicolumn{2}{|c|}{ Scale } & \multirow{2}{*}{$\begin{array}{c}\text { Items } \\
5\end{array}$} & \multirow{2}{*}{$\begin{array}{c}\text { Cronbach's Alpha } \\
0.872\end{array}$} & \multirow{2}{*}{$\begin{array}{c}\mathbf{C R} \\
0.917\end{array}$} & \multirow{2}{*}{$\begin{array}{l}\text { AVE } \\
0.691\end{array}$} & \multirow[t]{2}{*}{ Factor Loading } \\
\hline \multirow{10}{*}{$\begin{array}{c}\text { Supportive Work } \\
\text { Environment }\end{array}$} & Supervisor Support & & & & & \\
\hline & MAS1 & & & & & .931 \\
\hline & MAS2 & & & & & .873 \\
\hline & MAS3 & & & & & .836 \\
\hline & MAS5 & & & & & .793 \\
\hline & MAS6 & & & & & .660 \\
\hline & Co-worker Support & 5 & 0.919 & 0.854 & 0.545 & \\
\hline & $\operatorname{COS} 1$ & & & & & .794 \\
\hline & $\cos 2$ & & & & & .786 \\
\hline & COS3 & & & & & .752 \\
\hline
\end{tabular}




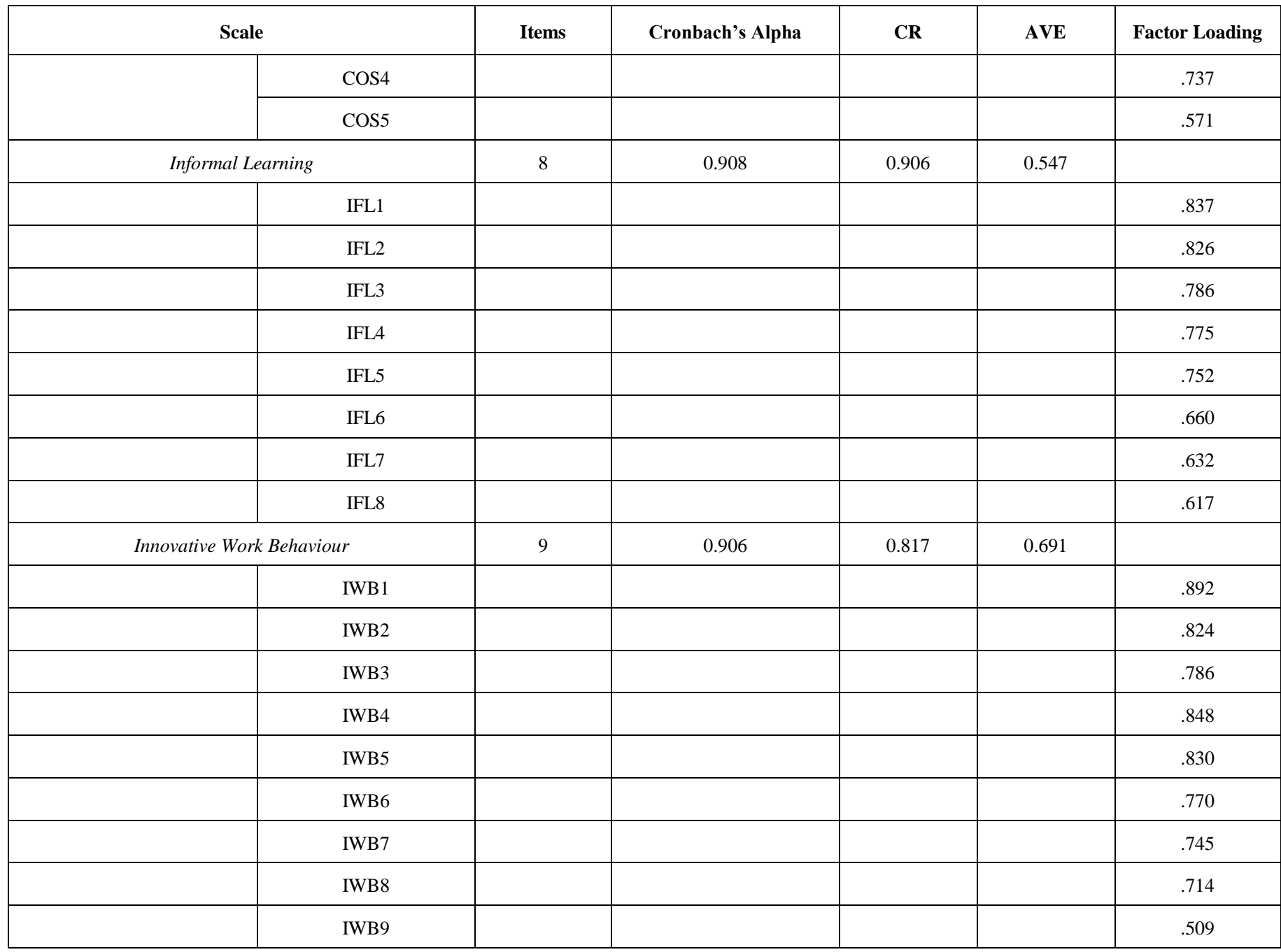

To test the model fit, these indices were used: Chi-squared $(\mathrm{P}>5 \%)$; Chi-square/degree of freedom ratio (CMIN/DF $<3$; Goodness of fit index $(\mathrm{GFI} \approx 1)$; Comparative fit index (CFI > 0.9); Tucker \& Lewis index (TLI > 0.9) and Root Mean Square Error of Approximation (RMSEA $<0.08)$.

Table 2: Model Fit Indices.

\begin{tabular}{|c|c|c|c|c|c|}
\hline Indices & Cmin/DF & CFI & GFI & TLI & RMSEA \\
\hline Conditions & $<3.0$ & $>0.9$ & $>0.9$ or $>0.8$ & $>0.9<0.08$ \\
\hline Analysis results & 2.106 & 0.955 & 0.907 & 0.950 & 0.049 \\
\hline
\end{tabular}

According to CFA results, the restricted model has 316 degrees of freedom and the chi-square is 665.487 , with P-value $=0.000$. Chi-square/df $=2.106$, which is acceptable as it should be between 1 and 3, as concluded by Hair et al. (2009). CFI $=0.955$; GFI $=0.907$ and TLI $=0.950$, satisfying the conditions of being higher than 0.9. Therefore, the model fits. For RMSEA, according to Hair et al. (2009), it should be less than 0.05 for a good model fit. Hence, it can be concluded that the model fits the data.

\subsection{Research Hypothesis Test}

The structural equations modelling method through the AMOS software was used to test the research model and hypotheses. The Maximum Likelihood Estimation (MLE) was also used to estimate the parameters of the model.

\section{Structural Equations Modelling Test}

Based on model fit indices in Table 2, all coefficients were acceptable, including: i) Chi-square/df $=2.276 \leq 3$; ii) $\mathrm{GFI}=$
0.901, TLI $=0.942$; and CFI $=0.948$, all $>0.9$; iii) RMSEA $=0.052 \leq 0.08$. Obviously, the model fits the data.

\section{Direct Impact Test}

These hypotheses need to be tested: i) the relationship between a supportive work environment (management support and co-worker support) and innovative teaching behaviour of general teachers and ii) the relationship between informal learning and the innovative teaching behaviour of general teachers. 


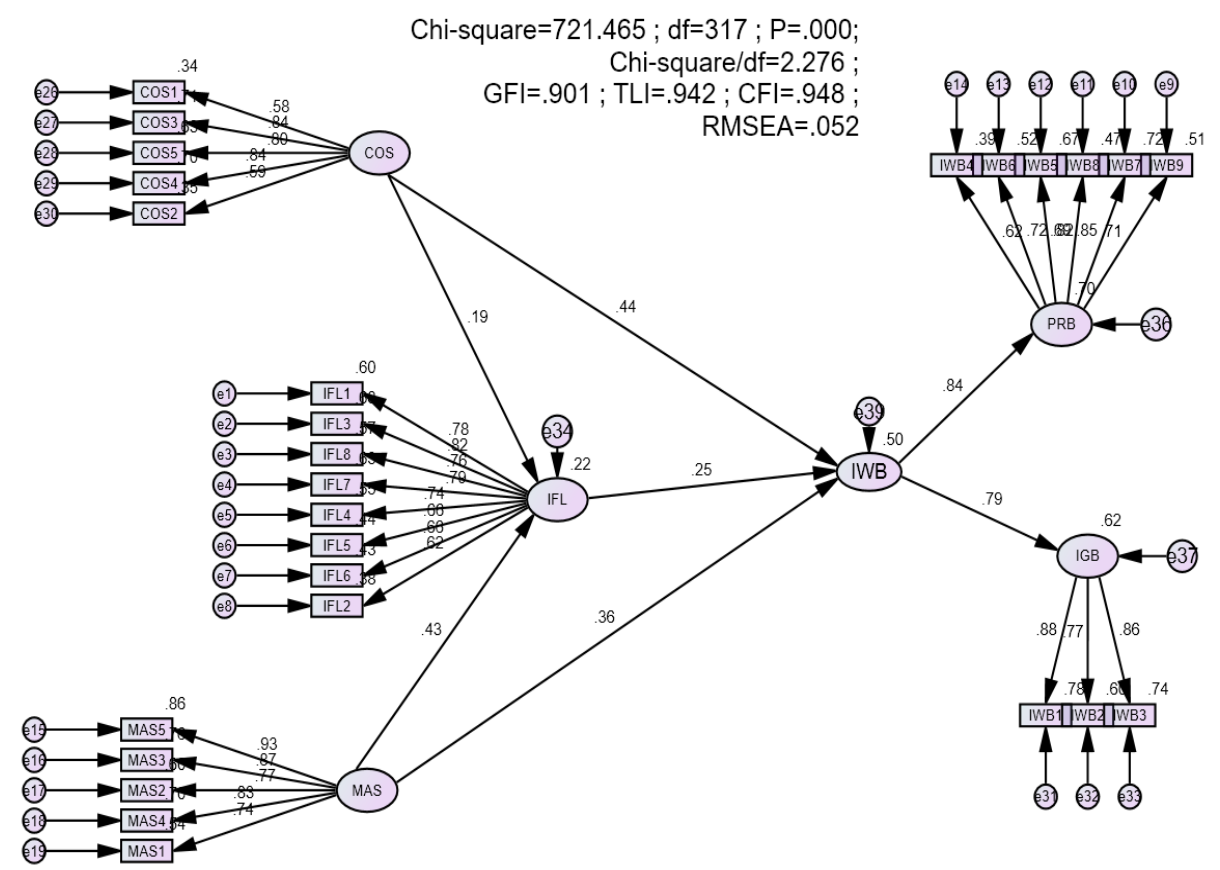

Fig. (2). Structural model test.

Table 3. Research Model's Hypothesis Test Results.

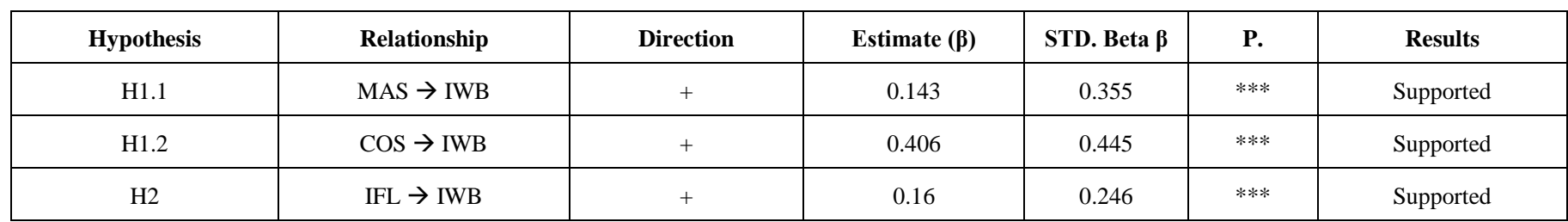

Regarding the SEM test, test results are considered statistically significant when $P_{\text {_ }}$ value $<5 \%$. Thus, according to the results in Table 3, P-value $<5 \%$, and it can be concluded that the variables have impacts on each other. Also, unstandardised positive weights show that management support, coworker support and informal learning all positively impact general teachers' innovative work behaviour.

In addition, standardised regression coefficients indicate that among driving forces of innovative teaching behaviour, coworker support is the most powerful factor, followed by management support and lastly informal learning.

\section{Mediator Direct Impact Test}

A variable is called a mediator variable when it explains the relationship between the independent variable and the dependent variable (Baron \& Kenny, 1986). A mediator variable is expected to satisfy the following three conditions:

Condition 1: The independent variable explains the variability of the mediator variable $(\beta 2 \neq 0)$

Condition 2: The mediator variable explains the variability of the dependent variable $(\beta 3 \neq 0)$

Condition 3: The presence of the mediator variable (with $\beta 2$ and $\beta 3$ ) will undermine the relationship between the independent variable and the dependent variable $(\beta 1 \mathrm{M}<\beta 1)$, in which $\beta 1$ is the regression weight between $\mathrm{X}$ and $\mathrm{Y}$ without the presence of the mediator variable $\mathrm{M}$.

According to Iacobucci et al. (2007): i) full mediation is when the direct impact of the independent variables on the dependent variable (with a mediator variable) is not statistically significant, and the indirect impact is statistically significant; ii) partial mediation is when the direct impact of the independent variables on the dependent variable (with a mediator variable) is statistically significant, and the indirect impact is statistically significant.

To check whether informal learning acts as a mediator variable in the relationship between COS and IWB, between MAS and IWB, SEM analysis and Bootstrapping were applied to test the direct and indirect impacts of COS and IWB, MAS, and IWB through IFL. As per results, when IFL variables were involved in the study model, the direct impact of COS on IWB was 0.445 (statistically significant with pvalue $<5 \%$ ), the indirect impact of COS on IWB through IFL was 0.047 (statistically significant with $\mathrm{p}=0.002<5 \%$ ). So, the IFL variable was a partial mediator variable between COS and IWB. Similarly, when IFL was involved in the study model, the direct impact of MAS on IWB was 0.355 (statistically significant with p-value $<5 \%$ ), the indirect impact of MAS on IWB through IFL was 0.105 (statistically significant with $\mathrm{p}=0.001<5 \%$ ). The IFL variable was as a 
partial mediator variable in the relationship between MAS and IWB.

\section{DISCUSSION AND CONCLUSIONS}

This research aims to explore the relationship between three factors: A supportive work environment, informal learning and innovative work behaviour. Therefore, with the three proposed hypotheses, the results are similar yet more insightful than previous scientific studies. In particular:

For hypothesis 01: The impact of a supportive work environment (from management and Co-workers) on the innovative work behaviour of general teachers is positive. This is consistent with previous studies of Janssen (2005), Montani et al. (2012), Prieto \& Pérez-Santana (2014) or Rehman et al. (2019). However, as a more insightful finding of this study, co-worker support has a stronger impact than management support. Meanwhile, this support impacts all aspects of general teachers' innovative work behaviour rather than only idea promotion and idea realisation as per Binnewies \& Groomer's (2012) findings. Accordingly, innovative teaching behaviour is more likely to increase with higher level of organisational support, especially from coworkers.

For hypothesis 02: Regarding the impact of informal learning on innovative work behaviour, the results are consistent with Lecat et al. (2018) that informal learning has a positive impact on innovative work behaviour. Once teachers are proactively engaged in informal learning, innovative work behaviour is also likely to increase.

For hypothesis 03: Informal learning is a mediator variable in the relationship between the supportive work environment and innovative work behaviour. Research results show that a supportive work environment promotes not only innovative work behaviour but also the informal learning of teachers. When informal learning is conducted, the impact of the supportive work environment on innovative work behaviour ceases. The important role of teachers' informal learning is reaffirmed. Even with a good supportive work environment at school, innovative work behaviour will not happen if teachers are not engaged in informal learning activities.

In summary, in the current context, this research is one of the few studies in Vietnam that conduct an analysis of the relationship between a supportive work environment, informal learning and innovative work behaviour. Therefore, the scale and research results may be regarded as references for future researchers to use, modify and supplement. This research's results also provide a specific perspective on the innovative work behaviour of Vietnamese teachers nowadays. At the same time, this research is able to measure the relationship between learning and innovative teaching behaviour. On that basis, policymakers and school leaders will be able to decide on appropriate human resources management policies to promote innovative teaching behaviour. Specifically, with the strong impact of informal learning on innovative teaching behaviour, this activity needs further encouragement from the schools and the Ministry of Education and Training. Teachers should be motivated to perceive gaining knowledge and information as a meaningful activity. Communication and interaction with co-workers should also be executed more frequently to help each individual promote innovative ideas and find ways to implement them (Lecat et al., 2018). Teachers also need to be proactive in learning to enhance their knowledge and expertise. In short, to achieve continuous teaching innovation, not only collaboration among stakeholders in the education system but also each teacher's learning efforts is of vital importance.

\section{CONFLICT OF INTEREST STATEMENT}

The authors declare that they have no conflict of interest.

\section{REFERENCES}

Amabile, T. M., Conti, R., Coon, H., Lazenby, J., \& Herron, M. (1996). Assessing the work environment for creativity. Academy of Management Journal, 39(5), 1154-1184.

Anderson, N., Potočnik, K., \& Zhou, J. (2014). Innovation and creativity in organizations: A state-of-the-science review, prospective commentary, and guiding framework. Journal of Management, 40(5), 12971333.

Baron, R. M., \& Kenny, D. A. (1986). The moderator-mediator variable distinction in social psychological research: Conceptual, strategic, and statistical considerations. Journal of Personality and Social Psychology, 51(6), 1173

Bawuro, F. A., Shamsuddin, A., Wahab, E., \& Usman, H. (2019). Mediating role of meaningful work in the relationship between intrinsic motivation and innovative work behaviour. International Journal of Scientific and Technology Research, 8(9), 2076-2084.

Berg, S. A., \& Chyung, S. Y. Y. (2008). Factors that influence informal learning in the workplace. Journal of Workplace Learning, 20(4), 229-244. https://doi.org/10.1108/13665620810871097

Bhanthumnavin, D. (2003). Perceived social support from supervisor and group members' psychological and situational characteristics as predictors of subordinate performance in Thai work units. Human Resource Development Quarterly, 14(1), 79-97.

Birdi, K., Leach, D., \& Magadley, W. (2016). The relationship of individual capabilities and environmental support with different facets of designers' innovative behavior. Journal of Product Innovation Management, 33(1), 19-35.

Blume, B. D., Ford, J. K., Baldwin, T. T., \& Huang, J. L. (2010). Transfer of training: A meta-analytic review. Journal of Management, 36(4), 1065-1105.

Borasi, R., \& Finnigan, K. (2010). Entrepreneurial Attitudes and Behaviors that Can Help Prepare Successful Change-Agents in Education. New Educator, 6(1), 1-29. https://doi.org/10.1080/1547688X.2010.10399586

Calantone, R. J., Cavusgil, S. T., \& Zhao, Y. (2002). Learning orientation, firm innovation capability, and firm performance. Industrial Marketing Management, 31(6), 515-524. https://doi.org/10.1016/S0019-8501(01)00203-6

Çokpekin, Ö., \& Knudsen, M. P. (2012). Does organizing for creativity really lead to innovation? Creativity and Innovation Management, 21(3), 304-314.

Cormier-MacBurnie, P., Doyle, W., Mombourquette, P., \& Young, J. D. (2015). Canadian chefs' workplace learning. European Journal of Training and Development.

De Jong, J. P., \& Den Hartog, D. N. (2008). Innovative work behavior: Measurement and validation. EIM Business and Policy Research, 8(1), 1-27.

De Spiegelaere, S., Van Gyes, G., \& Hootegem, G. Van. (2012). Job design and innovative work behavior: One size does not fit all types of employees. Journal of Entrepreneurship, Management and Innovation (JEMI), 8(4), 5-20.

Eisenberger, R., Stinglhamber, F., Vandenberghe, C., Sucharski, I. L., \& Rhoades, L. (2002). Perceived supervisor support: contributions to perceived organizational support and employee retention. Journal of Applied Psychology, 87(3), 565.

Eraut*, M. (2004). Informal learning in the workplace. Studies in Continuing Education, 26(2), 247-273.

Evers, C. W. (2012). Organisational contexts for lifelong learning: Individual and collective learning configurations. In Second international handbook of lifelong learning (pp. 61-76). Springer. 
George, J. M. (2007). 9 Creativity in organizations. Academy of Management Annals, 1(1), 439-477.

Gkorezis, P. (2016). Principal empowering leadership and teacher innovative behavior: a moderated mediation model. International Journal of Educational Management, 30(6), 1030-1044. https://doi.org/10.1108/IJEM-08-2015-0113

Hair, J. F., Black, W. C., Babin, B. J., Anderson, R. E., \& Tatham, R. L. (2009). Multivariate data analysis 7th Edition. Pearson Prentice Hall.

Hashim, N. H., Yaakob, M. F. M., Yusof, M. R., \& Ibrahim, M. Y. (2019). Innovative behavior among teachers: Empirical evidence from high-performance schools. International Journal of Innovative Technology and Exploring Engineering, 8(10), 1395-1399. https://doi.org/10.35940/ijitee.J9015.0881019

Hoyt, J., \& Gerloff, E. A. (1999). Organizational environment, changing economic conditions, and the effective supervision of technical personnel: A management challenge. The Journal of High Technology Management Research, 10(2), 275-293.

Huhtala, H., \& Parzefall, M. (2007). A review of employee well-being and innovativeness: An opportunity for a mutual benefit. Creativity and Innovation Management, 16(3), 299-306.

Hunter, S. T., \& Cushenbery, L. (2011). Leading for innovation: Direct and indirect influences. Advances in Developing Human Resources, 13(3), 248-265.

Iacobucci, D., Saldanha, N., \& Deng, X. (2007). A meditation on mediation: Evidence that structural equations models perform better than regressions. Journal of Consumer Psychology, 17(2), 139-153.

Jacobs, R. L., \& Park, Y. (2009). A proposed conceptual framework of workplace learning: Implications for theory development and research in human resource development. Human Resource Development Review, 8(2), 133-150.

Janssen, O. (2000). Job demands, perceptions of effort-reward fairness and innovative work behaviour. Journal of Occupational and Organizational Psychology, 73(3), 287-302.

Janssen, O. (2005). The joint impact of perceived influence and supervisor supportiveness on employee innovative behaviour. Journal of Occupational and Organizational Psychology, 78(4), 573-579.

Jeon, K. S., \& Kim, K.-N. (2012). How do organizational and task factors influence informal learning in the workplace? Human Resource Development International, 15(2), 209-226.

Joseph, K. E., \& Dai, C. (2009). The influence of organizational culture on organizational learning, worker involvement and worker productivity. International Journal of Business and Management, 4(9), 243250 .

Keskin, H. (2006). Market orientation, learning orientation, and innovation capabilities in SMEs: An extended model. European Journal of Innovation Management, 9(4), 396-417. https://doi.org/10.1108/14601060610707849

Klaeijsen, A., Vermeulen, M., \& Martens, R. (2018). Teachers' Innovative Behaviour: The Importance of Basic Psychological Need Satisfaction, Intrinsic Motivation, and Occupational Self-Efficacy. Scandinavian Journal of Educational Research, 62(5), 769-782. https://doi.org/10.1080/00313831.2017.1306803

Kleysen, R. F., \& Street, C. T. (2001). Toward a multi-dimensional measure of individual innovative behavior. Journal of Intellectual Capital.

Kraimer, M. L., \& Wayne, S. J. (2004). An examination of perceived organizational support as a multidimensional construct in the context of an expatriate assignment. Journal of Management, 30(2), 209-237.

Kwakman, K. (2003). Factors affecting teachers' participation in professional learning activities. Teaching and Teacher Education, 19(2), $149-170$.

Lecat, A., Beausaert, S., \& Raemdonck, I. (2018). On the Relation Between Teachers' (In)formal Learning and Innovative Working Behavior: the Mediating Role of Employability. Vocations and Learning, 11(3), 529-554. https://doi.org/10.1007/s12186-018-9199-x

Lee, H., \& Choi, B. (2003). Knowledge management enablers, processes, and organizational performance: An integrative view and empirical examination. Journal of Management Information Systems, 20(1), 179-228.

Li, M., \& Hsu, C. H. C. (2016). A review of employee innovative behavior in services. International Journal of Contemporary Hospitality Management, 28(12), 2820-2841. https://doi.org/10.1108/IJCHM04-2015-0214

Lohman, M. C. (2009). A survey of factors influencing the engagement of information technology professionals in informal learning activi- ties. Information Technology, Learning \& Performance Journal, 25(1).

Madjar, N. (2005). The contributions of different groups of individuals to employees' creativity. Advances in Developing Human Resources, 7(2), 182-206.

Madjar, N., Oldham, G. R., \& Pratt, M. G. (2002). There's no place like home? The contributions of work and nonwork creativity support to employees' creative performance. Academy of Management Journal, 45(4), 757-767.

Manuti, A., Pastore, S., Scardigno, A. F., Giancaspro, M. L., \& Morciano, D. (2015). Formal and informal learning in the workplace: a research review. International Journal of Training and Development, 19(1), 1-17.

Marsick, V. J., \& Volpe, M. (1999). The nature and need for informal learning. Advances in Developing Human Resources, 1(3), 1-9.

Marsick, V. J., \& Watkins, K. E. (2001). Informal and incidental learning. New Directions for Adult and Continuing Education, 2001(89), 25.

McCharen, B., Song, J. H., \& Martens, J. (2011). School innovation: The mutual impacts of organizational learning and creativity. Educational Management Administration and Leadership, 39(6), 676694. https://doi.org/10.1177/1741143211416387

Messmann, G., \& Mulder, R. H. (2011). Innovative work behaviour in vocational colleges: Understanding how and why innovations are developed. Vocations and Learning, 4(1), 63-84.

Messmann, G., \& Mulder, R. H. (2012). Development of a measurement instrument for innovative work behaviour as a dynamic and context-bound construct. Human Resource Development International, 15(1), 43-59.

Mohammad, R. F., \& Harlech-Jones, B. (2008). Working as partners for classroom reform. International Journal of Educational Development, 28(5), 534-545. https://doi.org/10.1016/j.ijedudev.2008.01.006

Montani, F., Odoardi, C., \& Battistelli, A. (2012). Explaining the relationships among supervisor support, affective commitment to change, and innovative work behavior: The moderating role of coworker support. BPA-Applied Psychology Bulletin (Bollettino Di Psicologia Applicata), 264.

Nemeržitski, S., Loogma, K., Heinla, E., \& Eisenschmidt, E. (2013). Constructing model of teachers innovative behaviour in school environment. Teachers and Teaching: Theory and Practice, 19(4), 398418. https://doi.org/10.1080/13540602.2013.770230

Noe, R. A., \& Kodwani, A. D. (2018). Employee training and development, 7e. McGraw-Hill Education.

Nunnally, J. C., \& Bernstein, I. H. (1994). Psychometric theory. McGrawHill.

Oldham, G. R., \& Cummings, A. (1996). Employee creativity: Personal and contextual factors at work. Academy of Management Journal, 39(3), 607-634.

Parker, S. K., Williams, H. M., \& Turner, N. (2006). Modeling the antecedents of proactive behavior at work. Journal of Applied Psychology, 91(3), 636.

Poell, R. F. (2013). Workplace learning theories and practices. Human Resource Development: Practices and Orthodoxies, 19-32.

Prieto, I. M., \& Pérez-Santana, M. P. (2014). Managing innovative work behavior: the role of human resource practices. Personnel Review.

Rehman, W. U., Ahmad, M., Allen, M. M. C., Raziq, M. M., \& Riaz, A. (2019). High involvement HR systems and innovative work behaviour: the mediating role of psychological empowerment, and the moderating roles of manager and co-worker support. European Journal of Work and Organizational Psychology, 28(4), 525-535.

Robinson, R. N. S., \& Beesley, L. G. (2010). Linkages between creativity and intention to quit: An occupational study of chefs. Tourism Management, 31(6), 765-776.

Schussler, D. L., Poole, I. R., Whitlock, T. W., \& Evertson, C. M. (2007). Layers and links: Learning to juggle "one more thing" in the classroom. Teaching and Teacher Education, 23(5), 572-585. https://doi.org/10.1016/j.tate.2007.01.016

Scott, S. G., \& Bruce, R. A. (1994). Determinants of Innovative Behavior: A Path Model of Individual Innovation in the Workplace. Academy of Management Journal, 37(3), 580-607. https://doi.org/10.1049/iet-rsn:20080009

Shalley, C. E., \& Gilson, L. L. (2004). What leaders need to know: A review of social and contextual factors that can foster or hinder creativity. The Leadership Quarterly, 15(1), 33-53. 
Skule, S. (2004). Learning conditions at work: a framework to understand and assess informal learning in the workplace. International Journal of Training and Development, 8(1), 8-20.

Thurlings, M., Evers, A. T., \& Vermeulen, M. (2015). Toward a Model of Explaining Teachers' Innovative Behavior: A Literature Review. Review of Educational Research, 85(3), 430-471. https://doi.org/10.3102/0034654314557949

Tracey, J. B., \& Tews, M. J. (2005). Construct validity of a general training climate scale. Organizational Research Methods, 8(4), 353-374.

Tynjälä, P. (2008). Perspectives into learning at the workplace. Educational Research Review, 3(2), 130-154.

https://doi.org/10.1016/j.edurev.2007.12.001
West, M. A., \& Farr, J. L. (1990). Innovation and creativity at work: Psycological and organizational strategies. John Wiley.

Zainal, M. A., \& Matore, M. E. E. M. (2019). Factors Influencing Teachers' Innovative Behaviour: A Systematic Review. Creative Education, 10(12), 2869-2886. https://doi.org/10.4236/ce.2019.1012213

Zhou, J., \& George, J. M. (2001). When job dissatisfaction leads to creativity: Encouraging the expression of voice. Academy of Management Journal, 44(4), 682-696.

Copyright (C 2021- All Rights Reserved

This is an open-access article. 